\title{
Growth status and menarcheal age among adolescent school girls in Wannune, Benue State, Nigeria
}

\author{
Daniel T Goon ${ }^{1}$, Abel L Toriola² ${ }^{2}$, Jonathan Uever ${ }^{3}$, Sarah Wuam, Olutoyin M Toriola ${ }^{5}$
}

\begin{abstract}
Background: Menarcheal age is a sensitive indicator of environmental conditions during childhood. The aim of study is to determine the age at menarche and growth status in adolescents in a rural area of Tarka, Wannune, Nigeria.

Methods: Data on 722 female students (aged 12-18 years) were collected in February 2009. Height and weight were measured. Body mass index (BMl; $\mathrm{kg} \mathrm{m}^{-2}$ ) was used as an index of relative weight.

Results: Mean and median menarcheal age calculated by probit analysis were 13.02 (SD 3.0) (95\% Cl: 13.02-13.07), and age 13.00 (SD 2.8) (95\% Cl: 12.98-13.04), respectively. Girls who reach menarche are significantly heavier and taller with higher BMls than those of their pre-menarcheal peers.

Conclusion: The age of menarche is probably still declining in Nigeria. Although BMI is an important factor in the onset of menstruation, some other unmeasured environmental variables may be implicated in this population.
\end{abstract}

\section{Background}

Menarcheal age is the most widely used indicator of sexual maturation and is known to be influenced by genetic factors, environmental conditions, body stature, family size, body mass index (BMI), socioeconomic status and level of education [1-3]. It is the most accurately recalled indicator of puberty among girls [4]. It varies between individuals and populations [5]. Female anthropometry that reveals body composition has shown strong influence on their reproductive characteristics marked by the menarcheal age [6]. An early menarcheal age is associated with increased risk for breast cancer [7], obesity [8], endometrial cancer [9] and uterine leiomyomata [10]. Also, several studies have reported that age at menarche may relate to subsequent reproductive performance, such as age at first intercourse, age at first pregnancy and risk of subsequent miscarriage [11].

The adolescent age group (10-19 years of age) constitutes about $23 \%$ of Nigeria's population [12] and this proportion is projected to be stable in the foreseeable

\footnotetext{
* Correspondence: toriolaal@tut.ac.za

${ }^{2}$ Department of Sports, Rehabilitation and Dental Sciences, Tshwane

University of Technology, Pretoria, South Africa

Full list of author information is available at the end of the article
}

future. There is strong evidence to confirm that these adolescents are sexually active [13]. Tarka is a relatively new local government council in Nigeria, which is disadvantaged in terms of health and socio-economic indicators. Reliable information about sexuality, contraception and sexually transmitted infections in Tarka Local Government Area (LGA) is lacking. For the majority of people in the local government, sexuality and menstruation are still social taboos.

Several studies have reported age at menarche to have declined in developed countries [14-16] and this decline has also been noted in developing countries $[17,18]$. Generally, these declines have been associated with improvements in nutritional status and general health along with many environmental factors. The downward trend seems to have halted in some countries [19]. The age of girls who start menstruating is an important factor in health planning, especially relating to the provision of sanitary facilities, health information concerning menstruating and contraception in primary and secondary schools, and the establishment of adolescent health centres [20].

The relationship between growth and menarche remains debatable. Stark et al [21] content in their study 
that in affluent individuals nutrition is relatively unimportant. Other studies have indicated that girls who attain menarche are significantly heavier and taller with higher BMIs than those of their pre-menarcheal peers [22,23].

Age at menarche has been reported in several parts of the world [14-16], including eastern, western and northern Nigeria [24-35]. Most of these studies were based on urban samples with limited information available on the menarcheal age of Nigerian girls living in rural communities. Data on menarcheal age may be used to improve health promotion services for girls in rural areas which are often neglected in terms of socio-economic development. The aim of this study was to examine the relationship between current age at menarche and growth status in a cross-section of adolescent girls in Wannune, Tarka LGA, Nigeria.

\section{Methods \\ Sample}

This anthropometric survey involved 722 students with an average age of 16.19 years (range: $12-18$ years old), attending five government-approved secondary schools in Tarka, Nigeria. Tarka LGA is one of the 23 local government councils in Benue State, Nigeria. With an estimated 134, 123 inhabitants [12], its administrative headquarter is based in Wannune. This relatively new LGA of Benue State is situated in a rural setting, and the major occupation of the people is farming. Others are either employed in white-collar jobs or are involved in private businesses. There were six secondary schools in Wannune as at the time of this study. Most children from all the districts come to live and attend school in the area. Therefore, children who attend schools which participated in this study come from all the districts. This indicates that participants of the study represent a cross-section of children in the area. Participants were selected by simple randomization technique. Parents and schools authorities approved the study protocol before data collection. The Area Education Office of Tarka LGA gave ethical approval for the study. The survey was carried out in February 2009.

\section{Anthropometric measures}

Stature and body mass were determined according to the standard anthropometric methods of the International Society for the Advancement of Kinanthropometry (ISAK) [36]. Stature was measured to the nearest 0.1 $\mathrm{cm}$ in bare feet with participants standing upright against a wall-mounted stadiometer. Body mass was measured to the nearest $0.5 \mathrm{~kg}$ with participants lightly dressed (underwear and T-shirt) using a portal digital scale (Tanita HD 309, Creative Health Products, MI, USA). BMI was calculated from the ratio of body mass $(\mathrm{kg}) /$ stature $\left(\mathrm{m}^{-2}\right)$. Anthropometric measurements were conducted by the author (DTG), a level II ISAK anthropometrist.

\section{Menarcheal age}

Menarcheal status was based on confidential questionnaire responses about date of birth, whether or not the girls had started menstruating, and age of onset in years and months. The different ages were regrouped in classes of 1 year each and were represented by the sign $+[22]$.

\section{Statistical analysis}

Age at menarche was calculated from date of menarche (month and year) and date of birth. Probit analysis was performed to determine the age at menarche for all girls by estimating the age at which $10,25,50,75$, and $90 \%$ of the girls reached menarche. Analysis was carried out with SPSS software version 17.0. The level of significance was set at $\mathrm{p} \leq 0.05$.

\section{Results}

A total of 761 girls who were studied, 39 were excluded due to incomplete data. Consequently, 722 questionnaires were analysed. The girls' mean age was $16.19 \pm$ 1.51 years (min. 12, max. 18). Mean BMI was $22.1 \pm 2.5$ $\mathrm{kg} \mathrm{m}^{-2}$, with $5.0 \%$ of Tarka girls classified as underweight, (BMI < 5th centile of WHO reference) [37]. Figures for overweight and obesity were $9.9 \%$. Distributions of girls according to their age at menarche and those who had not had experienced menarche based on age at the time of the survey is shown in Table 1. A small number of girls started menstruating before the age of 12 years; $5(16.4 \%)$ at age 10 (completed years), and 8 $(37.0 \%)$ at age 11. A total of $674(65.2 \%)$ respondents experienced menarche. The mean and median ages at menarche among the girls were 13.02 (SD 3.0) (95\% CI: 13.02-13.07) and 13.00 (SD 2.8) years (95\% CI: $12.98-$

Table 1 Number and percentage of menstruating girls (average age for each age band is $x+0.5$ years)

\begin{tabular}{|c|c|c|c|c|}
\hline & & $\begin{array}{c}\text { Menstruating } \\
\text { girls }\end{array}$ & & $\begin{array}{c}\text { Non-menstruating } \\
\text { girls }\end{array}$ \\
\hline Age & $\begin{array}{c}\text { Total number of } \\
\text { girls }\end{array}$ & $n$ & $\%$ & $n$ \\
\hline $12+$ & 30 & 13 & 53.4 & 17 \\
\hline $13+$ & 31 & 18 & 58.1 & 13 \\
\hline $14+$ & 67 & 58 & 86.6 & 9 \\
\hline $15+$ & 115 & 112 & 97.4 & 3 \\
\hline $16+$ & 150 & 147 & 97.4 & 3 \\
\hline $17+$ & 170 & 167 & 97.4 & 3 \\
\hline $18+$ & 159 & 159 & 100.0 & \\
\hline Total & 722 & 674 & & 48 \\
\hline
\end{tabular}


Table 2 Growth status of menstruating (post-) and non-menstruating (pre-) girls

\begin{tabular}{|c|c|c|c|c|c|c|c|c|}
\hline \multirow[b]{2}{*}{ Age } & \multicolumn{2}{|c|}{$n=722$} & \multicolumn{2}{|c|}{ Height $(\mathrm{cm})$} & \multicolumn{2}{|c|}{ Weight (kg) } & \multicolumn{2}{|c|}{ BMI $\left(\mathrm{kg} \mathrm{m}^{-2}\right)$} \\
\hline & Pre- & Post- & Pre- & Post- & Pre- & Post- & Pre- & Post- \\
\hline $12+$ & 17 & 13 & $148.1 \pm 6.0$ & $159.0 \pm 6.1$ & $45.8 \pm 8.2$ & $49.8 \pm 4.2^{*}$ & $18.7 \pm 2.6$ & $20.2 \pm 3.0^{*}$ \\
\hline $13+$ & 13 & 18 & $151.1 \pm 4.8$ & $153.7 \pm 5.6^{*}$ & $48.0 \pm 6.7$ & $51.4 \pm 5.6^{*}$ & $21.0 \pm 2.8$ & $21.8 \pm 2.4$ \\
\hline $14+$ & 9 & 58 & $151.6 \pm 5.2$ & $155.5 \pm 5.3^{*}$ & $49.0 \pm 4.1$ & $52.2 \pm 7.0^{*}$ & $21.3 \pm 2.2$ & $21.6 \pm 2.6$ \\
\hline $15+$ & 3 & 112 & $146.2 \pm 6.7$ & $155.9 \pm 5.9^{*}$ & $42.2 \pm 9.8$ & $53.5 \pm 6.5^{*}$ & $19.5 \pm 2.6$ & $22.0 \pm 2.4^{*}$ \\
\hline $16+$ & 3 & 147 & $153.3 \pm 4.6$ & 156. $1 \pm 5.8^{*}$ & $48.3 \pm 5.3$ & 54. $1 \pm 7.3^{*}$ & $20.4 \pm 2.4$ & $22.1 \pm 2.5^{*}$ \\
\hline $17+$ & 3 & 167 & $154.5 \pm 5.3$ & $156.9 \pm 5.6^{*}$ & $52.4 \pm 5.6$ & $55.6 \pm 7.9^{*}$ & $20.1 \pm 3.4$ & $22.5 \pm 2.9^{*}$ \\
\hline \multirow[t]{2}{*}{$18+$} & 0 & 159 & & $158.1 \pm 6.2$ & & $55.1 \pm 6.1$ & & $22.0 \pm 2.2$ \\
\hline & 48 & 674 & & & & & & \\
\hline
\end{tabular}

${ }^{*} \mathrm{p}<0.01$

13.04), respectively. The prevalence of primary amenorrhoea (no menstruation yet at the age of 16 years and more) was $2.6 \%$ (six of 320 respondents).

Table 2 compares the anthropometric data according to menarcheal status. The mean values for height, weight and BMI were higher among the post-menarcheal girls compared to their pre-menarcheal contemporaries. The mean weight and BMI were significantly higher for menstruating girls in nearly all the age groups, while there were significant differences in height for ages 13-17 years.

Predictors of the onset of menstruation are shown in Table 3. Unadjusted odds ratios indicate, as expected, that older age and higher BMI were positively associated with attainment of menarche. Being only child too, was highly predictive.

\section{Discussion}

Menarcheal age was assessed by status quo technique in 722 school girls in Tarka municipality, Nigeria. Among the girls the mean and median ages at menarche were 13.02 and 13.00 years, respectively. The findings contradict the accepted view of delayed menarcheal age in rural communities. The scale (around 1 year) of urbanrural differences lies within the range of variation observed in developing countries [38]. Our data suggest a trend of declining age of menarche in Nigerian girls. Table 4 provides a comparison of mean age at menarche in the present study with those reported in other
Nigerian studies. Menarcheal age in this study is slighter lower, but comparable to those reported in previous studies carried out in other parts of Nigeria [24-35], and greater than [24,25,32-34] those studies conducted in various settings. A recent study [35], among school girls in Kaduna, found menarcheal age of 12.81 years (SD 3.1) which is younger than the mean age in our study. Compared to most African and Asian studies, the age at menarche in our study is younger but older than those reported in most European and North American countries, which may reflect different environmental influences. The methods of collecting and analysing data vary in different studies. Thus, attempts at comparing menarcheal ages across studies should be done cautiously.

Recent longitudinal studies have consistently indicated that adiposity in early childhood predicts early puberty $[39,40]$. In our study, BMI was used as a measure of adiposity. The gain in body fat may be one of the key signals, possibly through secretion of the fat-derived protein leptin, for stimulating the hypothalamus to increase secretion of GnRH [41], which in turn stimulates the pituitary-ovarian axis and initiates the pubertal surge. Our findings indicate that girls who reach menarche are significantly heavier and taller with higher BMIs than those of pre-menarcheal status of same age group. This is consistent with findings which reported that BMI is a contributing factor in determining the age of onset of puberty $[23,42,43]$.

Table 3 Predictors of onset of menstruation

\begin{tabular}{|c|c|c|}
\hline & Unadjusted OR (95\% Cl) & Adjusted OR* $(95 \% \mathrm{Cl})$ \\
\hline Older age & $2.5(1.5-2.2)$ & $2.2(0.9-2.5)$ \\
\hline Higher BMI & $3.2(2.1-4.2)$ & $2.8(1.8-3.7)$ \\
\hline Higher level of father's education & $1.3(0.8-1.6)$ & not in model \\
\hline Higher level of mother's education & $1.1(0.5-1.4)$ & not in model \\
\hline Only child & $2.3(1.5-3.2)$ & $1.1(0.7-1.3)$ \\
\hline
\end{tabular}

*Logistics regression model: all listed variables included except parental education.

Age and BMI adjusted as continuous variables.

Higher education level defined as completion of at secondary school education to age 18 . 
Table 4 Studies on mean age at menarche in different regions

\begin{tabular}{|c|c|c|c|c|c|}
\hline Year & $\mathbf{n}$ & Age & Sample & Age at menarche ${ }^{1}$ & Reference \\
\hline 1949 & 250 & $8-18$ & Urban school girls (Lagos) & 14.3 & [33] \\
\hline 1960-1 & 335 & $12-19$ & Urban school girls (lbo) & $14.07 \pm 0.16$ & [34] \\
\hline \multirow[t]{2}{*}{$1973-4$} & 2029 & $10-17$ & urban school girls (Ibadan) & $13.7 \pm 0.03$ & [24] \\
\hline & 328 & & Rural & $14.5 \pm 0.09$ & \\
\hline \multirow[t]{3}{*}{1978} & 1365 & $10-18$ & All & 13. $54 \pm 0.07$ & [25] \\
\hline & 1216 & & Urban & $13.48 \pm 0.09$ & \\
\hline & 149 & & Semi-urban & $14.05 \pm 0.18$ & \\
\hline $1982-3$ & 2207 & $10-19$ & Urban (Enugu) & $13.3 \pm 1.09$ & {$[26]$} \\
\hline 1985 & & & Mixed (Ilorin) & $13.7 \pm 1.0$ & {$[27]$} \\
\hline \multirow[t]{5}{*}{1990} & & & School girls (lle-lfe) & $13.4 \pm 1.4$ & [28] \\
\hline & 5736 & $11-18$ & School girls & $13.42 \pm 1.51$ & [29] \\
\hline & 352 & $13-15$ & Urban school girls & $13.94 \pm 1.31$ & [30] \\
\hline & 859 & & Urban school girls (Portharcourt) & $13.19 \pm 1.32$ & {$[32]$} \\
\hline & & & Rural school girls (Etche) & $14.22 \pm 1.47$ & \\
\hline \multirow[t]{2}{*}{2006} & 358 & $12-18$ & School girls (Kaduna) & $12.81 \pm 1.31$ & {$[35]$} \\
\hline & 900 & $10-20$ & Urban school girls (Portharcourt) & $13.43 \pm 2.19$ & {$[31]$} \\
\hline 2009 & 722 & $12-18$ & Rural school girls (Tarka) & $13.02 \pm 3.0$ & [Present study] \\
\hline
\end{tabular}

${ }^{1}$ Years, median/mean \pm SD.

The prevalence of amenorrhea in our study was $2.6 \%$ (six of 320 respondents who were aged 16 years and older), which falls slightly below the reported prevalence of $3-4 \%[44,45]$. According to Frisch et al [46] in addition to there being a critical weight at which menarche occurs, there is a critically low weight in relation to height at which amenorrhoea develops. A sizeable percentage of the adolescents were underweight (5.0\%), therefore the likelihood of amenorrhea is obvious. A study by Ayatollahi et al [47] found that underweight delayed menarche by about 3 months and 3 weeks. Age at menarche is delayed especially in populations with poor nutrition $[2,48]$, and historically, improved nutrition and socioeconomic status has been attributed to causing a decline in the age of menarche $[49,50]$. The small number of amenorrhea noted in the present study could be ascribed to lesser stress and better nutrition, but this claim needs further investigation. A previous research reported that undernutrition delays menarche and adolescent growth spurt, which normally precedes menarche [51].

\section{Conclusions}

Our data seem to support the theory that BMI is a key factor in the onset of menarche [22,52]. However, as the study was cross-sectional, a cause and effect relationship could not be ascertained. Some of the differences in menarcheal age are likely to be due to other environmental variables which were not included in the study's design such as socio-economic status and general living conditions. Although early menarcheal age may lead to increased body weight, high BMI can in turn cause early menarche and persist in the postmenarcheal period. The findings of the present study support earlier ones and indicate a rate of decline in age at menarche. Also, age at menarche is not delayed in this rural region of Nigeria; rather, it is comparable to urban findings. Improved living conditions may possibly be responsible for the parity.

\section{Acknowledgements}

To the students for volunteering to participate, parents for their consent and various school principals for granting permission to carry out the study.

\section{Author details}

${ }^{1}$ Centre for Biokinetics, Recreation and Sport Science, University of Venda, Thohoyandou, South Africa. ${ }^{2}$ Department of Sports, Rehabilitation and Dental Sciences, Tshwane University of Technology, Pretoria, South Africa. ${ }^{3}$ Department of Human Kinetics and Health Education, Benue State University, Makurdi, Nigeria. ${ }^{4}$ Department of Physical and Health Education, College of Education, Katsina-Ala, Nigeria. ${ }^{5}$ Department of Primary Education (Physical Education Unit), University of Swaziland, Kwaluseni, Swaziland.

\section{Authors' contributions}

DTG was the primary investigator for the study, designed the study, supervised data collection and wrote the paper. ALT advised on data collection, analysed the data and helped write the paper. JU participated in designing the study, analysing the data and writing the paper. SW and OMT advised on the design of the study, the analysis of the findings and writing of the paper. All authors read and approved the final manuscript.

\section{Competing interests}

The authors declare that they have no competing interests.

Received: 17 January 2010 Accepted: 19 August 2010 Published: 19 August 2010

\section{References}

1. Chumlea WC, Schubert CM, Roche AF, Kulin HE, Lee PA, Himes JH, Sun SS: Age at menarche and racial comparisons in US girls. Paediatrics 2003, 111:110-113. 
2. Thomas F, Renaud F, Benefice E, de Meeus T, Guegan JF: International variability of ages at menarche and menopause: patterns and main determinants. Human Biology 2001, 73:271-290.

3. Ayatollahi SMT, Dowlatabadi E, Ayatollahi SAR: Age at menarche and its correlates in Shuraxz southern Iran. Iranian Journal of Medical Sciences 1999, 24:20-25.

4. Cole TJ: The secular trend in human physical growth: a biological view. Economics and Human Biology 2003, 1:161-68.

5. Katsunori F, Shinichi D: Relationship between change in BMI with age and delayed menarche in female athletes. Journal of Physiology and Anthropology 2003, 22:97-104.

6. Lassek WD, Gaulin SJC: Menarche is related to fat distribution. American Journal of Physical Anthropology 2006, 131:295-302.

7. Braithwaite D, Moore DH, Lustig RH, Epel ES, Ong KK, Rehkopf DH, Wang MC, Miller SM, Hiatt RA: Socioeconomic status in relation to early menarche among black and white girls. Can Causes Control 2009, 20:713-20.

8. Van Lenthe FJ, Kemper CG, van Mechelen W: Rapid maturation in adolescence results in greater obesity in adulthood: The Amsterdam Growth and Health Study. American Journal of Clinical Nutrition 1996, 64:18-24.

9. McPherson CP, Sellers TA, Potter JD, Bostick RM, Folsom AR: Reproductive factors and risk of endometrial cancer. The lowa Women's Health Study. American Journal of Epidemiology 1996, 143(1195):1202.

10. Marshall LM, Spiegelman D, Goldman MB, Manson JE, Colditz GA, Barbieri RL, Stampfer MJ, Hunter DJ: A prospective study of reproductive factors and oral contraceptive use in relation to the risk of uterine leiomyomata. Fertility and Sterility 1998, 70:432-39.

11. Schor N: Abortion and adolescence: relation between the menarche and sexual activity. International Journal of Adolescence Medicine and Health 1993, 6:225-40.

12. National Population Commission: 1991 Population census of the Federal Republic of Nigeria: analytical report at the national level. Abuja 1998.

13. Federal Office of Statistics 1990: Nigeria Demographic and Health Survey. Lagos 1990.

14. Anderson SE, Dallai GE, Must A: Relative weight and race influence average age at menarche: results from two nationally representative surveys of US girls studied 25 years apart. Paediatrics 2003, 111:844-50.

15. Anderson SE, Must A: Interpreting the continued decline in the average age at menarche: results from two nationally representative surveys of US girls studied 10 years apart. Journal of Paediatrics 2005, 147(753):60.

16. Biro FM, Huang B, Crawford PB, Lucky AW, Striegel-Moore R, Barton BA, Daniels S: Pubertal correlates in black and white girls. Journal of Paediatrics 2006, 148:234-240.

17. Hosny LA, El-Ruby MO, Zaki ME, Agian MS, Zaki MS, El Gammal MA Mazen IM: Assessment of pubertal development in Egyptian girls. Journal of Paediatrics and Endocrinology Metabolism 2005, 18:577-84.

18. Hwang JY, Shin C, Frongillo EA, Shin KR, JO I: Secular trend in age at menarche for South Korean women born between 1920 and 1986: The Ansan Study. Annals of Human Biology 2003, 30:434-42.

19. Whincup PH, Gilg JA, Odoki K, Taylor SJC, Cook DG: Age at menarche in contemporary British teenagers: survey of girls born between 1982 and 1986. British Medical Journal 2001, 322:1095-6.

20. Ekerbicer HC, Celik M, Kiran H, Kiran G: Age at menarche in Turkish adolescents in Kahramanmaras, eastern Mediterranean region of Turkey. European Journal of Contraceptive and Reproductive Health Care 2007, 12:289-93.

21. Stark O, Peckham CS, Moynihan C: Weight and age at menarche. Archives of Disease Child 1989, 64:383-7.

22. Hesketh T, Ding QJ, Tomkins A: Growth status and menarche in urban and rural China. Annals of Human Biology 2002, 29:348-52.

23. Janssens J, Vandeloo M, Alonso A, Brukers L, Molenberghs G: Lifestyle factors and puberty in girls. Proc American Society of Clinical Oncology 2003, 22:97, (abstr 388).

24. Oduntan SO, Ayeni O, Kale OO: The age of menarche in Nigerian girls. Annals of Human Biology 1976, 3:269-74.

25. Uche GO, Okorafor AE: The age of menarche in Nigerian urban schoolgirls. Annals of Human Biology 1979, 6:395-8.

26. Modebe $\mathrm{O}$ : The effect of homozygous cell disease on the age at menarche in Nigerians schoolgirls. Annals of Human Biology 1987, 14:181-5.
27. Fakeye $\mathrm{O}$ : The inter-relationship between age, physical measurements and body composition at menarche in school girls at llorin, Nigeria. International Journal of Gynaecology and Obstetrics 1985, 23:55-8.

28. Thomas KD, Okonofua FE, Chiboka O: A study of the menstrual patterns of adolescents in Ile-Ife, Nigeria. International Journal of Gynaecology and Obstetrics 1990, 33:31-4.

29. Rehan N: Characteristics of the menarche in Hausa girls in Nigeria. Journal of Obstetrics and Gynaecology 1994, 14:265-8.

30. Abioye-Kuteyi EA, Ojofeitimi EO, Aina OI, Kio F, Aluko Y, Mosuro O: The influence of socio-economic and nutritional status on menarche in Nigeria school girls. Nutrition and Health 1997, 11:185-95.

31. Ofuya MZ: The age at menarche in Nigerian adolescents from two different socio-economic classes. Online Journal of Health Allied Sciences 2007, 6:1-4.

32. Ikaraoha Cl, Mbadiwe IC, Igwe CU, Allagua DO, Mezie O, Iwo GTO, Ofori PI: Menarcheal age of secondary school girls in urban and rural areas of Rivers State, Nigeria. Online Journal of Health Allied Sciences 2005, 4:1-4.

33. Ellis RWB: Age at puberty in the tropics. British Medical Journal 1950 10:85-89.

34. Tanner JM, O'Keeffe B: Age at menarche in Nigerian school girls with a note on their heights and weights from age 12 to 19. Human Biology 1962, 34:187-96.

35. Sule ST, Ukwenya JE: Menstrual experiences of adolescents in a secondary school. Journal of Turkish-German Gynaecological Association 2007, 8:7-14.

36. Marfell-Jones M, Olds T, Stew A, Carter L: International standards for anthropometric assessment. The International Society for the Advancement of Kinanthropometry. Australia 2006.

37. World Health Organization Expert Committee: Physical status: the use and interpretation of anthropometry. Report of a WHO expert committee. Technical report series 854 WHO Geneva 1995.

38. Eveleth PB, Tanner JM: Worldwide variation in human growth Cambridge: Cambridge University Press 1990.

39. Davison KK, Susman EJ, Birch LL: Percent body fat at age 5 predicts earlier pubertal development among girls at age 9. Paediatrics 2003, 111:815-21.

40. Lee JM, Appugliese D, Kaciroti N, Corwyn RF, Bradley RH, Lumeng JC: Weight status in young girls and the onset of puberty. Paediatrics 2007, 119:E624-E30.

41. Wilson ME, Fisher J, Chikazawa K, Yoda R, Legendre A, Mook D, Gould KG: Leptin administration increases nocturnal concentration of luteinizing hormone and growth hormone in juvenile female rhesus monkeys. Journal of Clinical Endrocrinology and Metabolism 2003, 88:4874-83.

42. Kaplowitz PB, Slora EJ, Wasserman RC, Pedlow SE, Herman-Gidens ME: Earlier onset of puberty in girls: relation to increased body mass index and race. Paediatrics 2001, 108:347-53.

43. Sloboda DM, Hart R, Doherty DA, Penell CE, Shickey M: Prenatal and post natal growth. Journal of Clinical Endocrinology and Metabolism 2007, 92:46-50.

44. American Society for Reproductive Medicine: Current evaluation of amenorrhea. Fertility and Sterility 2004, 82:S33-S9.

45. Danborno B, Oyibo JE: Anthropometric and menstrual characteristics of girls from Nigeria and Niger Republic. Internet Journal of Biological Anthropology 2008, 2:1.

46. Frisch E, McArthur WJ: Menstrual cycles: fatness as a determinant of minimum weight for height necessary for their maintenance of onset. Sciences 1974, 185:947-951.

47. Ayatollahi SMT, Dowlatabadi E, Ayatollahi SAR: Age at menarche in Iran. Annals of Human Biology 2002, 29:355-62.

48. Gluckman PD, Hanson MA: Evolution, development and timing of puberty. Trends Endocrinology and Metabolism 2006, 17:7-12.

49. Chodick G, Rademaker A, Balicer MH, Davidovitch MG: Secular trends in age at menarche, smoking and oral contraceptive use among Israeli girls. Preventive Chronic Disease 2005, 2:A12.

50. Hauspie RC, Vercuateren M, Susanne C: Secular changes in growth and maturation: an update. Acta Paediatrics 1997, 432:20-27.

51. Frisch RE: Weight at menarche: similarity for well-nourished and undernourished girls at different ages and evidence for historical constancy. Paediatrics 1972, 50:445.

52. Tanner JM: Trend towards earlier menarche in London, Oslo, Copenhagen, the Netherlands and Hungary. Nature 1973, 243:95-6. 


\section{Pre-publication history}

The pre-publication history for this paper can be accessed here: http://www.biomedcentral.com/1471-2431/10/60/prepub

doi:10.1186/1471-2431-10-60

Cite this article as: Goon et al:: Growth status and menarcheal age among adolescent school girls in Wannune, Benue State, Nigeria. BMC

Pediatrics 2010 10:60

Submit your next manuscript to BioMed Central and take full advantage of:

- Convenient online submission

- Thorough peer review

- No space constraints or color figure charges

- Immediate publication on acceptance

- Inclusion in PubMed, CAS, Scopus and Google Scholar

- Research which is freely available for redistribution

Submit your manuscript at 